Ryszard Skubisz ${ }^{1}$

\title{
UZYSKANIE CHARAKTERU ODRÓŻNIAJĄCEGO PRZEZ ZNAK TOWAROWY POPRZEZ UŻYWANIE (PRZESŁANKI, DATA I DOWODY NABYCIA)
}

\section{Uwagi ogólne}

Rozwój gospodarki rynkowej, wyrażający się w podwyższeniu jej konkurencyjności, powoduje wzrost znaczenia oznaczeń odróżniających, w szczególności znaków towarowych. Zapewniają one bowiem komunikację przedsiębiorcy z potencjalnym nabywcą towarów pod tym znakiem poprzez przekazywanie informacji o tych towarach. W rezultacie nabywca może odszukać na rynku wśród wielu produktów te właśnie pochodzące od przedsiębiorcy, który używa tego znaku. Dzięki znakowi nabywcy otrzymują informacje, iż wszystkie tak samo oznaczone towary pochodzą z jednego i tego samego źródła. Potencjalny odbiorca nie przypisuje tym towarom pochodzenia $\mathrm{z}$ tego samego źródła w znaczeniu fizycznym. To pochodzenie jest rozumiane w znaczeniu komercyjnym. Przeciętny nabywca postrzega znak towarowy jako informację, iż wszystkie tak samo oznaczone towary zostały wprowadzone do obrotu za zgodą uprawnionego do znaku towarowego. Nie ma znaczenia osoba rzeczywistego wytwórcy całości produktu lub jego części składowych, jak również miejsca ich wytworzenia, montażu, opakowania itd.

Przekazując wskazane informacje znak towarowy wykonuje funkcję oznaczenia pochodzenia. ${ }^{2}$ Jest to pierwotna funkcja znaku towarowego, która wynika $\mathrm{z}$ jego istoty. Wykonywanie tej funkcji jest możliwe tylko wtedy, gdy oznaczenie ze względu na swoją strukturę i sposób użycia, może być postrzegane przez konsumentów, jako informacja o pochodzeniu towarów pod tym znakiem. Innymi słowy,

$1 \quad$ Profesor zwyczajny, doktor habilitowany, Kierownik Katedry Prawa Unii Europejskiej Wydziału Prawa i Administracji Uniwersytetu Marii Curie-Skłodowskiej; rzecznik patentowy i radca prawny. denasty dyrektywy), jak również sądy unijne w orzeczeniach publikowanych w języku polskim, określają tę funkcję jako „wskazania pochodzenia” (np. wyrok Trybunału Sprawiedliwości z dnia 18 czerwca 2009 r., w sprawie C-487/07 L'Oreal, Zb.Orz. 2009, s. II-5185, pkt 60. Ta odmienność terminologiczna jest nieistotna z punktu widzenia treści tej funkcji. 
znak towarowy może wykonywać funkcję oznaczenia pochodzenia, jeżeli jest wyposażony w cechę określaną jako zdolność odróżniająca. W braku tej cechy, choćby oznaczenie było używane w obrocie w związku z towarem, potencjalni nabywcy nie są w stanie, na jego podstawie, zidentyfikować na rynku towary pochodzące od określonego przedsiębiorcy.

Oznaczenie może charakteryzować się zdolnością odróżniającą ze względu na swoją strukturę (pierwotna zdolność odróżniająca). Może jednak również nabyć taką zdolność poprzez używanie w obrocie gospodarczym w związku z konkretnym towarem (wtórna zdolność odróżniająca).

Przedmiotem niniejszego tekstu jest próba określenia najważniejszych zagadnień dotyczących wtórnej zdolności odróżniającej. Są to przesłanki jej nabycia, data stanowiąca podstawę jej nabycia, jak również dowody nabycia, włącznie z zagadnieniem ciężaru dowodu. Punktem wyjścia jest określenie pojęcia ,zdolność odróżniająca”, jej postaci oraz znaczenia. Przedstawienie stanowiska autora odnośnie do tych zagadnień pozwoli na przeprowadzenie charakterystyki szczegółowych kwestii wchodzących w obszar wtórnej zdolności odróżniającej. ${ }^{3}$

Podstawę normatywną stanowią przepisy ustawy prawo własności przemysłowej. ${ }^{4}$ Przepisy tej ustawy powinny być interpretowane i stosowane przy wykorzystaniu wykładni przepisów prawa Unii Europejskiej. Taki obowiązek sądów i Urzędu Patentowego wynika z obowiązku lojalnego wykonywania obowiązku państwa członkowskiego Unii Europejskiej (art. 4 ust. 3 TFUE). Dlatego konieczne jest również uwzględnienie wyroków Trybunału Sprawiedliwości wydanych w trybie odpowiedzi na pytania w trybie prejudycjalnym (art. 267 Traktatu o funkcjonowaniu Unii Europejskiej). ${ }^{5}$ Ustalają one bowiem treść norm prawa unijnego i ich uwzględnienie w toku wykładni przepisów prawa polskiego jest bezwzględnie konieczne. Trybunał jest bowiem powołany do interpretacji przepisów prawa unijnego.

W zakresie zagadnień objętych tematem niniejszego artykułu podstawowe znaczenie mają wyroki Trybunału Sprawiedliwości o charakterze prejudycjalnym dotyczące przepisów dyrektywy Parlamentu Europejskiego i Rady 2008/95 z dnia 22 października 2008 r. mającej na celu zbliżenie ustawodawstw państw członkowskich odnoszących się do znaków towarowych. ${ }^{6}$ Jedynie pomocniczy charakter mają na-

Niniejsza wypowiedź stanowi kontynuację badań autora w dziedzinie zdolności odróżniającej, zob. R. Skubisz, Zdolność odróżniająca znaku towarowego w prawie europejskim i w prawie polskim, (w:) Sądownictwo Administracyjne Gwarantem Wolności i Praw Obywatelskich, 1980-2005, Warszawa 2005, s. 374-394; Zdolność odróżniająca znaku towarowego w orzecznictwie Trybunału Sprawiedliwości Wspólnot Europejskich, (w:) A. Adamczak (red.), Wspólnotowe i krajowe regulacje prawne w dziedzinie ochrony władności przemysłowej, „Urząd Patentowy Rzeczypospolitej Polskiej" 2005, nr 29, s. 111.

$4 \quad$ Ustawa prawo własności przemysłowej z dnia 30 czerwca 2000 r. (Dz.U. z 2013 r. poz. 1410 - dalej p.w.p.).

$5 \quad$ Dz. Urz. UE C115 z dnia 9 maja 2008 r., s. 47 - dalej TFUE.

6 Dz. Urz. UE z dnia 8 listopada 2008 r., L 299/25, dyrektywa ta zastąpiła Pierwszą dyrektywę Rady nr 89/104/EWG z dnia 21 grudnia 1988 r. mająca na celu zbliżenie ustawodawstw państw członkowskich odnoszących się do znaków towarowych (Dz. Urz. WE z 1989 r., nr L 40, s. 1; tekst w j. polskim opublikowany w: Dz. Urz. Polskie wydanie specjalne 2004, rozdz. 17, t.1, s. 92). Dyrektywa 2008/95 nie wprowadziła zmian w regulacji charakteru odróżniającego w stosunku do dyrektywy nr 89/104. Dlatego w całej rozciągłości jest nadal aktualne wcześniejsze orzecznictwo i piśmiennictwo dotyczące zdolności odróżniającej, zob. w tej kwestii wyrok TS z dnia 19 czerwca 
tomiast wyroki Sądu Unii Europejskiej i Trybunału Sprawiedliwości wydane w następstwie skargi na decyzję Urzędu Harmonizacji w ramach Rynku Wewnętrznego (znaki towarowe i wzory przemysłowe) w Alicante. ${ }^{7}$ Te orzeczenia, inaczej niż wydane w trybie odpowiedzi na pytania wstępne, nie wiążą bowiem Urzędu Patentowego RP, sądów administracyjnych i sądów powszechnych oraz Sądu Najwyższego. Niewątpliwie stanowią one jednak cenne źródło informacji o stosowaniu analogicznych norm rozporządzenia Rady (WE) nr 207/2009 z 26 lutego 2009 r. w sprawie wspólnotowego znaku towarowego. ${ }^{8}$

\section{Charakter odróżniający znaku towarowego. Charakterystyka ogólna}

Przepisy p.w.p. w zamierzeniu ustawodawcy miały na celu, obok kilku innych, implementację dyrektywy o znakach towarowych. Pomijając w tym miejscu zagadnienia oceny całościowej realizacji tego celu ${ }^{9}$ należy wskazać, iż w zakresie regulacji zdolności odróżniającej wzorcem unijnym są przepisy art. 2 i art. 3 tej dyrektywy. Dlatego wskazane jest przeprowadzenie krótkiej charakterystyki tych przepisów.

Przepis art. 2 dyrektywy definiuje pojęcie znaku towarowego. W świetle tego przepisu znak towarowy powinien spełniać następujące przesłanki. Po pierwsze, musi być to oznaczenie rozumiane jako pewne quid, które jest jako takie postrzegane i rozpoznawane wśród wielu innych. Po drugie, musi ono nadawać się do przedstawienia w sposób graficzny. To przedstawienie oznaczenia musi być jasne, precyzyjne, kompletne, łatwo dostępne, trwałe i obiektywne (graficzna przedstawialność). Po trzecie, nadaje się do odróżniania towarów jednego przedsiębiorstwa od towarów innych przedsiębiorstw. Wystarczy, iż to oznaczenie nadaje się do odróżniania jakiegokolwiek towaru lub usługi. ${ }^{10}$ Ta cecha jest określana jako abstrakcyjna zdolność odróżniania znaku towarowego. ${ }^{11}$ Jeżeli oznaczenie zawarte w zgłoszeniu, nie re-

2014 w sprawach połączonych C-217/12 i 218/13 Oberbank AG (C-217/13) Banco Santander S.A. (C-218/13), Santander Consumer Bank (C-218/13) Santander Consumerbank AG p. Deutscher Sparkassen- und Giroverband e.V., pkt 31, www.curia.europa.eu (data dostępu: 11.09.2015 r.).

7 Dalej OHIM.

8 Dz. Urz. UE z 24.3.2009, L 78/1 rozporządzenie to zastąpiło rozporządzenie Rady WE z 20 grudnia 1993 r. o znaku towarowym Wspólnoty (Dz. Urz. z 1994 r., Nr L 011/1).

9 Zob. w tej kwestii R. Skubisz, (w:) System Prawa Prywatnego. Prawo własności przemysłowej, t. XIV b, Warszawa 2012, s. 38-40

10 Zob. wyrok TS z 6.5.2003 r. w sprawie C-104/01, Libertel Groep BV przeciwko Benelux-Markenbureau, Zb. Orz. z 2003 r., s. I-3793, pkt 39-41, tekst w j. polskim (przekład M. Mazurek), (w:) R. Skubisz (red.), Własność przemysłowa. Orzecznictwo Trybunału Sprawiedliwości Wspólnot Europejskich i Sądu Pierwszej Instancji, Kraków 2006, poz. 18.

11 Zob. szerzej na tle art. 4 ustawy z dnia 31 stycznia 1985 r. R. Skubisz, Glosa do wyroku Naczelnego Sądu Administracyjnego z 23.11.2004 r., II GSK 864/04, OSP 2005, nr 9, poz. 108, E. Wojcieszko-Głuszko, (w:) System Prawa Prywatnego. Prawo własności przemysłowej, t. XIV b, s. 432-434. W orzecznictwie Trybunału jest określana jako ogólna zdolność oznaczenia do tego, aby mogło stać się znakiem towarowym, zob. powołany wyżej wyrok TS w sprawach połączonych C-217/13 i 208/13, Oberbank, pkt 37, wyrok TS z 24.6.2004 r., w sprawie C-49/02 Heidelberger Bauchemie GmbH, pkt 22, wyrok TS z dnia 25 stycznia 2007 r. w sprawie C-321/03 Dyson Ltd przeciwko Registrar of Trade Marks, pkt 28, www.curia.europa.eu (data dostępu: 11.09.2015 r.). 
alizuje wszystkich tych trzech przesłanek, to Urząd Patentowy powinien wydać decyzję o odmowie rejestracji. W razie udzielenia prawa ochronnego może ono zostać unieważnione.

Przepis art. 3 ust. 1 wyłącza od rejestracji lub w przypadku rejestracji umożliwia unieważnienie znaków towarowych, które są pozbawione charakteru odróżniającego (b), które składają się wyłącznie ze znaków lub oznaczeń mogących służyć w obrocie do oznaczenia rodzaju, jakości, ilości, przeznaczenia, wartości, pochodzenia geograficznego lub czasu produkcji towaru lub oświadczenia usług lub innych właściwości towarów lub usług (c), jak również znaki towarowe składające się wyłącznie ze znaków lub oznaczeń, które weszły do języka potocznego lub prowadzonych w dobrej wierze i utrwalonych praktykach handlowych.

Przepis art. 3 ust. 3 dyrektywy stanowi, iż: „Nie można odmówić rejestracji znaku towarowego ani stwierdzać jego nieważności zgodnie z ust. 1 lit. b), c) lub d), jeżeli przed datą złożenia wniosku o rejestrację i w następstwie jego używania znak ten uzyskał charakter odróżniający. Każde państwo członkowskie może ponadto postanowić, że niniejszy przepis będzie miał także zastosowanie, kiedy charakter odróżniający został uzyskany po dacie złożenia wniosku o rejestrację lub po dacie rejestracji”. Przytoczony przepis w zdaniu pierwszym sankcjonuje zatem nabycie charakteru odróżniającego przed datą zgłoszenia znaku towarowego. Natomiast w zdaniu drugim umożliwia państwom członkowskim wprowadzenie do swojego systemu prawnego normy przewidującej nabycie charakteru odróżniającego po dacie zgłoszenia lub po dacie rejestracji. Przepis art. 3 ust. 2 zd. 2 zawiera zatem normę fakultatywną. Państwa członkowskie mogą zatem przewidzieć możliwość nabycia wtórnej zdolności odróżniającej znaku towarowego także po dacie zgłoszenia lub po dacie rejestracji. Fakultatywny charakter normy nie może jednak być rozumiany jako dowolność regulacji przepisów dotyczących przeszkód rejestracji znaków towarowych. Ustawodawca krajowy, jeżeli korzysta z tej możliwości, to powinien jednak wprowadzić tę normę w postaci, w jakiej jest zawarta w dyrektywie. ${ }^{12}$ Państwo członkowskie ma zatem do wyboru następującą alternatywę - nie skorzystać z normy art. 3 ust. 2 zd. 2 dyrektywy, bądź wprowadzić ją do prawa wewnętrznego w postaci, jaka została przyjęta w dyrektywie. Ustawodawca krajowy nie ma natomiast innych możliwości postępowania, jeżeli chce pozostać w zgodzie z regulaznaku towarowego, na przykład brak charakteru odróżniającego /.../ powinny być wymienione w sposób wyczerpujący, nawet jeżeli niektóre z tych podstaw są wymienione, jako alternatywa dla państw członkowskich, które dzięki temu mogą utrzymać lub wprowadzić te podstawy do swoich przepisów prawnych (motyw 8 preambuły dyrektywy), zob. także w odniesieniu do skutków normy fakultatywnej art. 5 ust. 2 dyrektywy, wyrok TS z dnia 23 października 2003 r. w sprawie C-408/01 Adidas-Salomon AG (dawniej Adidas AG i Adidas Benelux BV p. Fitnessworld Trading Ltd., pkt 20, przekład na j. polski: M. Mazurek, (w:) R. Skubisz (red.), Własność przemysłowa orzecznictwo Trybunału Sprawiedliwości Wspólnot Europejskich i Sądu Pierwszej Instancji, Kraków 2006, poz. 19. 
cją prawa unijnego. Inna regulacja prawa krajowego w tej kwestii pozostawałaby w sprzeczności zarówno z literą, jak i duchem dyrektywy.

Ustawodawca $\mathrm{w}$ ustawie prawo własności przemysłowej podjął próbę transpozycji do prawa polskiego powołanych wyżej przepisów dyrektywy w art. $120 \mathrm{i}$ art. 129-130 oraz art. 165 ust. 1 pkt 2 p.w.p. Wyjść trzeba od stwierdzenia, iż z punktu widzenia tematu tej publikacji znaczenie ma unormowanie zdolności odróżniającej znaku towarowego. Legitymowanie się taką zdolnością jest koniecznym i najważniejszym, chociaż nie jedynym, warunkiem udzielenia prawa ochronnego. Brak tej cechy oznaczenia prowadzi do odmowy udzielenia prawa. Natomiast w razie udzielenia prawa na znak pozbawiony charakteru odróżniającego prawo to podlega unieważnieniu, jeżeli zostanie wszczęte odpowiednie postępowanie.

Przepis art. 120 p.w.p. stanowi, iż znakiem towarowym może być każde oznaczenie, które można przedstawić w sposób graficzny, jeżeli oznaczenie takie nadaje się do odróżnienia towarów jednego przedsiębiorstwa od towarów innego przedsiębiorstwa. Przepis ten, chociaż literalnie odbiega od treści art. 2 dyrektywy, to jednak transponuje do prawa polskiego wymienioną normę. Dlatego powyższe uwagi, w tym dotyczące abstrakcyjnej zdolności odróżniającej, stosuje się w pełni do art. 120.

Zgodnie z art. 129 p.w.p. „Nie udziela się praw ochronnych na oznaczenia, które: 1) nie mogą być znakiem towarowym; 2) nie mają dostatecznych znamion odróżniających. 2. Z zastrzeżeniem art. 130 nie mają dostatecznych znamion odróżniających oznaczenia, które: 1) nie nadają się do odróżniania w obrocie towarów, dla których zostały zgłoszone; 2) składają się wyłącznie z elementów mogących służyć w obrocie do wskazania w szczególności rodzaju towaru, jego pochodzenia, jakości, ilości, wartości, przeznaczenia, sposobu wytwarzania, składu, funkcji lub przydatności; 3) weszły do języka potocznego lub są zwyczajowo używane w uczciwych i utrwalonych praktykach handlowych".

Przepis art. 130 p.w.p. stanowi, iż: ,Przy ocenie, czy oznaczenie ma dostateczne znamiona odróżniające, należy uwzględnić wszystkie okoliczności związane z oznaczaniem nim towarów w obrocie. Odmowa udzielenia prawa ochronnego na podstawie przepisu art. 129 ust. 1 pkt 2 nie może nastąpić w szczególności, jeżeli przed datą zgłoszenia znaku towarowego w Urzędzie Patentowym znak ten nabrał, w następstwie jego używania, charakteru odróżniającego w przeciętnych warunkach obrotu".

Według art. 165 ust. 1 pkt 2 p.w.p. stanowi, iż: „Z wnioskiem o unieważnienie prawa ochronnego nie można wystąpić po upływie pięciu lat od udzielenia prawa ochronnego, jeżeli prawo to udzielone zostało z naruszeniem przepisów art. 129, lecz znak w wyniku używania nabrał charakteru odróżniającego".

Przytoczone przepisy operują określeniem „dostateczne znamiona odróżniające” oraz „charakter odróżniający”. Są to synonimy określenia „zdolność odróżniająca", które nadal występuje w orzeczeniach Urzędu Patentowego oraz sądów i są używane w literaturze dotyczącej prawa znaków towarowych. 
Znak towarowy może charakteryzować się samoistnym bądź nabytym charakterem odróżniającym. Charakter odróżniający znaku towarowego zarówno samoistny, jak i nabyty poprzez używanie wyraża się w tym, że znak towarowy pozwala na identyfikację towaru lub usługi, dla których stanowi oznaczenie indywidualizujące i przez to odróżnia od towarów lub usług pochodzących z innych przedsiębiorstw. ${ }^{13}$

Ocena samoistnego charakteru odróżniającego oznaczenia jest niezależna od jego używania. Dotyczy ona wyłącznie tego, czy oznaczenie użyte w związku z towarem może odróżnić ten towar od innych towarów. Chodzi jedynie o to, czy ze swojej istoty to oznaczenie, w kontekście konkretnego towaru, w percepcji przeciętnego nabywcy tych towarów, może odróżnić te towary na podstawie ich pochodzenia z jednego i tego samego źródła. Ta zdolność może być o rozmaitym stopniu intensywności. W świetle dosłownego brzmienia art. 129 ustawy, znak towarowy powinien być zarejestrowany, pod warunkiem spełnienia innych przesłanek udzielenia prawa, nawet jeżeli legitymuje się tylko minimalnym stopniem charakteru odróżniającego. Powstaje zatem potrzeba rozgraniczenia pomiędzy koniecznym minimum charakteru odróżniającego a jego całkowitym brakiem. Problem ten jest już z pewnością nieaktualny w odniesieniu do trójwymiarowych (przestrzennych) znaków towarowych. Trybunał Sprawiedliwości stwierdza wprawdzie, iż kryteria oceny zdolności odróżniającej tych znaków są takie same jak wszystkich innych. ${ }^{14}$ Jednocześnie akcentuje jednak okoliczność, iż ,percepcja przeciętnego konsumenta nie jest koniecznie taka sama w przypadku znaku trójwymiarowego, składającego się z opakowania towaru, jak w przypadku znaku słownego albo graficznego (...). W rzeczywistości, przeciętni konsumenci nie są przyzwyczajeni domniemywać pochodzenia towaru na podstawie formy ich opakowania (...) toteż ustalenie zdolności odróżniającej mogłoby się okazać trudniejsze w odniesieniu do znaku trójwymiarowego niż w odniesieniu do znaku słownego lub graficznego (...)." ${ }^{15}$ Dlatego „w odniesieniu do znaków trójwymiarowych składających się z opakowania towarów, które są opakowywane w handlu z powodów związanych z samym charakterem towaru, zdolność odróżniająca (...) musi być określana w związku z percepcją należycie poinformowanego, uważnego i racjonalnego przeciętnego konsumenta tych towarów. Taki znak powinien pozwolić mu, bez przeprowadzania analizy lub porównania i bez wykazywania szczególnej uwagi, na odróżnienie danego towaru od to-

Wyrok TS z dnia 4 maja 1999 r., w sprawie C-109/97, Windsurfing Chiemsee Produktions- und Vertriebs GmbH (WSC) p. Boots- und Segelzbehör Walter Huber, Franz Attenberger, wyrok w tłum. E. Całka, w: R. Skubisz, Orzecznictwo Europejskiego Trybunału Sprawiedliwości 2003, poz. 119, pkt 46, wyrok TS z dnia 18 czerwca 2002 r. w sprawie C-289/99 Philips p. Remington Consumer Products Ltd., pkt 35; powołany wyżej wyrok TS z dnia 19 czerwca 2014 r., w połączonych sprawach C-217/12 i C-218/13 Oberbank i inn., pkt 38.

14 Wyrok TS z dnia 8 kwietnia 2003 r., w sprawie C-53/01, C-54/01 i C-55/01 Linde AG (C-53/01), Winward Industries Inc. (C-54/01) i Rado Uhren AG (C-55/01), pkt 40 i 47, zob. także wyrok Sądu Pierwszej Instancji z 15.12.2005 r. w sprawie T-262/04 BIC S.A. p. OHIM, pkt 24 i powołane tam orzecznictwo.

15 Zob. wyrok Trybunału Sprawiedliwości z dnia 12 lutego 2004 r. w sprawie C-218/01, Henkel, pkt 52, przekład na j. polski M. Mazurek, (w:) R. Skubisz (red.), Własność przemysłowa, Kraków 2006, poz. 25. 
warów innych przedsiębiorstw."16 Wynika z tego, iż trójwymiarowy znak towarowy charakteryzuje się zdolnością odróżniającą tylko wtedy, gdy „w sposób znaczący odbiega od normy lub zwyczajów branżowych i w związku z tym może pełnić podstawową funkcję wskazania na pochodzenie". ${ }^{17}$ Należy także zauważyć, że według Trybunału Sprawiedliwości ,im bardziej kształt, o którego rejestrację wystąpiono jest bliższy kształtowi towaru, tym większe jest prawdopodobieństwo, iż jest on pozbawiony charakteru odróżniającego". ${ }^{18} \mathrm{~W}$ przypadku płynów, gazów, materiałów piśmienniczych oraz sypkich, które są pozbawione określonej formy i postaci opakowania jest jedyną formą dostrzeganą przez konsumenta, którą można przedstawić graficznie. W takich przypadkach zastosowane opakowania nadają kształt produktowi i dlatego powinno być z nim utożsamiane. ${ }^{19}$ Powyższe uwagi dotyczące kształtu towarów odnoszą się zatem odpowiednio do opakowań na wskazane produkty.

Znacznie bardziej złożony jest problem słownych graficznych i kombinowanych znaków towarowych. Jak się wydaje, w orzecznictwie Trybunału brak dotąd wypowiedzi dotyczącej generalnej oceny minimalnego stopnia charakteru odróżniającego tych znaków. ${ }^{20}$ Dlatego ta ocena powinna być zarówno skierowana na okoliczności konkretnego stanu faktycznego. Można jednak zauważyć, iż wyroki Trybunału Sprawiedliwości dotyczące zdolności odróżniającej takich znaków towarowych - wydane zarówno w trybie odwoławczym, jak i o charakterze prejudycjalnym - rozstrzygają w istocie zagadnienie minimalnego poziomu charakteru odróżniającego.

Znak towarowy legitymuje się natomiast wtórną zdolnością odróżniającą wtedy, gdy użyty w związku z towarem wprawdzie początkowo nie przekazuje informacji o pochodzeniu towarów, ale później, wskutek używania, najczęściej intensywnego i w dłuższym okresie na znacznym terytorium, przekazuje taki komunikat odbiorcom. Oznaczenie wskutek używania zmienia zatem swój wcześniejszy, pierwotny charakter i staje się nośnikiem informacji o pochodzeniu towarów. Innymi słowy, takie oznaczenie, od chwili uzyskania właściwości odróżniania towarów według ich pochodzenia komercyjnego, zachowuje się na rynku jak znak towarowy, czyli jest znakiem towarowym.

W przypadku obydwu wymienionych postaci zdolności odróżniającej, inaczej niż przy zdolności abstrakcyjnej, oznaczenie identyfikuje określony rodzaj towaru wymieniony w zgłoszeniu znaku towarowego i tym samym odróżnia od towarów innych przedsiębiorstw. Ocena charakteru odróżniającego zawsze odnosi się do kon-

\footnotetext{
16 Zob. powołany wyżej wyrok Trybunału Sprawiedliwości z dnia 12 lutego 2004 r. w sprawie C-218/01, Henkel, pkt 53.

17 Zob. wyrok TS z dnia 12 stycznia 2006 r., w sprawie C-173/04 P, Deutsche SiSi-Werke GmbH \& Co. Betriebs KG p. OHIM, pkt 31 i powołane tam orzecznictwo.

18 Wyrok TS z dnia 7 października 2004 r., w sprawie C-136/02P Mag Instrument p. OHIM, pkt 31, www.curia.europa.eu (data dostępu: 11.09 .2015 r.).

19 Zob. powołany wyżej wyrok TS z dnia 12 lutego 2004 r. w sprawie C-218/07, Henkel, pkt 33.

20 Zob. opinia rzecznika generalnego J. Colomera, w sprawie C-24/05 Storck, pkt 47, www.curia.europa.eu (data dostępu: 11.09.2015 r.).
} 
kretnego towaru. Towar zgłoszony do rejestracji bądź już wymieniony w rejestrze znaków towarowych jest jasno określony. Dlatego ta zdolność jest nazywana konkretną zdolnością odróżniającą (zdolność odróżniająca in concreto).

Uzyskanie charakteru odróżniającego w następstwie używania zakłada legitymowanie się przez oznaczenie zdolnością abstrakcyjną. Brak zdolności do odróżniania dowolnego towaru wyłącza per se możliwość nabycia wtórnej zdolności odróżniającej. ${ }^{21}$ Jeżeli oznaczenie nie może w ogóle odróżniać jakichkolwiek towarów, to nie może przecież odróżniać także towarów wymienionych w zgłoszeniu. Obydwie przesłanki rejestracji znaku towarowego, abstrakcyjną i konkretną zdolność odróżniającą, należy ostro odróżnić.

W każdym przypadku charakter odróżniający znaku towarowego powinien być oceniany zarówno w stosunku do towarów (usług), dla których wystąpiono o rejestrację, jak i przy uwzględnieniu domniemanego sposobu jego postrzegania przez właściwych odbiorców. ${ }^{22}$

W odniesieniu do określonej kategorii towarów oznaczenie może mieć charakter opisowy, rodzajowy lub z innych powodów nie nadawać się do odróżniania towarów. To samo oznaczenie użyte $\mathrm{w}$ związku $\mathrm{z}$ innymi towarami może być uważane za fantazyjne i nadawać się do wypełniania funkcji właściwej znakom towarowym. Tak więc rodzaj towaru ma podstawowe znaczenie dla oceny charakteru odróżniającego.

Zasadnicze znaczenie dla oceny tego charakteru znaku towarowego ma pogląd przeciętnego odbiorcy towarów pod tym znakiem. Istotne jest bowiem odczytywanie tego oznaczenia przez modelowego nabywcę towarów pod znakiem, jako informacji o pochodzeniu towarów z jednego i tego samego źródła (pojedyncze przedsiębiorstwo lub związek przedsiębiorstw). W celu ustalenia poglądu przeciętnego odbiorcy należy dokonać następujących czynności. Najpierw zakreślić krąg nabywców tych towarów mając na uwadze, że do tego kręgu należą nie tylko aktualni, ale również potencjalni nabywcy towarów pod tym znakiem. Następnie typowe cechy tych osób ustala się wzorzec osoby dobrze poinformowanej, wystarczająco uważnej i racjonalnej. Charakter towaru ma zasadnicze znaczenie dla rekonstrukcji cech przeciętnego odbiorcy. ${ }^{23} \mathrm{Jak}$ już wyżej wskazano, takie normatywne ujęcie przeciętnego odbiorcy jest podstawą oceny zarówno samoistnego charakteru odróżniającego, jak i uzyskania charakteru odróżniającego przez znak towarowy w następstwie jego używania.

Przy ocenie charakteru odróżniającego istotne znaczenie mają wewnętrzne cechy znaku, w szczególności, czy zawiera on elementy opisowe dotyczące cech towarów zgłoszonych towarów. Składnik opisowy nie dyskwalifikuje bowiem znaku

21 Zob. wyrok TS z dnia 14 września 2010 r., w sprawie C-48/09P, Lego Juris A/S p. OHIM, pkt 40, www.curia.europa.eu (data dostępu: 11.09 .2015 r.).

22 Zob. zamiast wielu, powołane wyżej wyroki TS z dnia 18 czerwca 2002 r. w sprawie C-299/99 Philips, pkt 59 z dnia 22 czerwca 2006 r., w sprawie C-25/05 P Storck p. OHIM, pkt 25, z dnia 25 października 2007 r., zob. także wyrok w sprawie C-238/06 P Develey p. OHIM, pkt 79, z dnia 24 maja 2012 r., w sprawie C-98/11P Chocoladenfabriken Lindt \& Sprüngli AG p. OHIM, pkt 41, www.curia.europa.eu (data dostępu: 11.09.2015 r.). Zob. np. wyrok UE z dnia 25 września 2014 r., w sprawie T-474/12 Giorgio Giorgis p. OHIM, pkt 17. 
towarowego, jeżeli jako całość nadaje się do odróżniania towarów. Jeżeli jednak składa się wyłącznie z oznaczeń lub wskazówek opisowych lub z innych powodów pozbawionych zdolności odróżniającej w stosunku do zgłoszonych towarów, to nie powinien być zarejestrowany. ${ }^{24}$

Od zdolności odróżniającej znaku towarowego należy odróżnić jego rozpoznawalność w obrocie jako odrębną kategorię pojęciową. Obejmuje ona łącznie dwie właściwości znaku. Po pierwsze, zdolność (zdatność) oznaczenia do odróżniania konkretnych towarów na rynku według ich komercyjnego pochodzenia. Ta zdolność do odróżniania wynika ze struktury (istoty) znaku i jego związku z konkretnym towarem (usługą). Te cechy oznaczenia oraz szczególnie cechy towaru przesądzają, iż charakteryzuje ono pierwotną zdolność odróżniającą. Nie można wykluczyć, iż to oznaczenie użyte $\mathrm{w}$ związku $\mathrm{z}$ innym towarem będzie pełnić funkcje opisowe. Po drugie, znajomość znaku wśród odbiorców towarów pod tym znakiem. ${ }^{25}$ Jest ona wynikiem skali i czasu obecności towarów na rynku oraz zakresu i form ich reklamy. Znak towarowy może nabyć wysoką rozpoznawalność, także wtedy, gdy nie miał pierwotnej zdolności odróżniającej. Jednakże istnienie samoistnego charakteru odróżniającego niewątpliwie pozwala na szybkie uzyskanie znajomości znaku towarowego w obrocie. Drugi składnik rozpoznawalności znaku towarowego, jego znajomość, ma znaczenie podstawowe w praktyce. Dlatego rozpoznawalność jest niekiedy utożsamiana ze znajomością znaku towarowego w obrocie. W przypadku znaków pozbawionych samoistnego charakteru odróżniającego znajomość (rozpoznawalność) znaku towarowego jest równoznaczna z wtórną zdolnością odróżniającą.

Rozpoznawalność znaku towarowego jest kluczową przesłanką w toku ustalania, czy osoba trzecia, poprzez używanie tego oznaczenia bez zgody uprawnionego, wkracza w zakres prawa ochronnego, a tym samym narusza to prawo. ${ }^{26}$ Pominięcie rozpoznawalności znaku towarowego w procesie o naruszenie prawa ochronnego może prowadzić do wydania nieprawidłowego wyroku sądu.

\section{Przesłanki nabycia charakteru odróżniającego poprzez używanie znaku towarowego}

Przepis art. 130 przesądza, iż oznaczenie pozbawione pierwotnie charakteru odróżniającego może go nabyć poprzez używanie w obrocie. Kluczowe znaczenie ma zatem określenie warunków, których realizacja warunkuje uzyskanie charakteru

\footnotetext{
24 Zob. wyrok TS z dnia 12 lutego 2004 r. w sprawie C-363/99 Koninklijke KPN Nederland NV przeciwko Benelux-Merkenbureau, pkt 104, przekład na j. polski M. Mazurek, (w:) R. Skubisz (red.), Własność przemysłowa, poz. 10, wyrok TS z dnia 12 lutego 2004 r. w sprawie C-265/00, Campina Melkunie BV przeciwko Beneluks-Merkenbureau, przekład na j. polski M. Mazurek, (w:) R. Skubisz (red.), Własność przemysłowa, op. cit., poz. 24. 2012, s. 702-703. 
odróżniającego takich znaków towarowych. Analiza przepisów p.w.p. nie udziela jednak jasnej odpowiedzi w kwestii tych przesłanek. Dlatego konieczne jest ich ustalenie przede wszystkim na drodze wykładni funkcjonalnej przy wykorzystaniu stanowiska wyrażonego w judykaturze i piśmiennictwie. ${ }^{27}$

Odwołanie się do wykładni funkcjonalnej pozwala określić jako pierwszy warunek istnienie oznaczenia o cechach określonych w art. 120 powołanej ustawy. Skoro bowiem znak towarowy ma identyfikować towary na rynku, według ich pochodzenia komercyjnego, to nie ulega wątpliwości, iż musi być postrzegany, co najmniej pojęciowo, jako odrębny byt w stosunku do towaru (opakowania) $i$ innych danych dotyczących tego towaru. Musi być również graficznie przedstawialny i mieć zdolność do wyróżniania w obrocie towaru. Tak więc, pierwszą przesłanką nabycia zdolności odróżniającej poprzez używanie jest istnienie oznaczenia (znaku) zdefiniowanego w art. 120 p.w.p.

Drugą przesłanką jest używanie oznaczenia w charakterze znaku towarowego. Jest to wymóg używania oznaczenia w celu odróżniania towarów jednego przedsiębiorstwa od towarów innych przedsiębiorstw na podstawie kryterium ich pochodzenia. ${ }^{28}$ Również w tym przypadku należy mieć na uwadze funkcje wykonywane przez oznaczenie w obrocie gospodarczym. Oznaczenie może bowiem być używane na towarze, jego opakowaniu, itd. w rozmaitych celach (np. jako cena, określenie okresu przydatności, dekoracja). Tylko jedną z wielu możliwych sposobów użycia oznaczenia może być jego używanie w celu zidentyfikowania towaru na rynku i przez to odróżnienie od towarów innych przedsiębiorstw. Nie ma przy tym znaczenia intencja przedsiębiorcy towarzysząca używaniu oznaczenia. Podstawowe znaczenie przesądzające charakter używania ma bowiem pogląd nabywców tych towarów. Jeżeli rozpoznają oni to oznaczenie w następstwie jego używania, jako nośnik informacji o pochodzeniu towaru, to jest to użycie w charakterze znaku towarowego. Natomiast w sytuacji, gdy to oznaczenie jest przez nich uważane za określenie produktu (jako nazwa) lub jego właściwości, bądź nie ma ono jakiegokolwiek czytelnego przekazu dotyczącego towaru, to nie można mówić, iż jest używane jako znak towarowy. ${ }^{29}$

Zob. w najnowszej literaturze zwięzłe przedstawienie przesłanek nabycia wtórnej zdolności odróżniającej M. Mazurek, E. Pijewska, Ocena zdolności odróżniającej znaku towarowego (wybrane problemy), (w:) Materialnoprawne i procesowe problemy ochrony dóbr intelektualnych, ze szczególnym uwzględnieniem obrotu takimi dobrami, „Zbiór referatów z seminarium rzeczników patentowych szkół wyższych” Cedzyna 15-19.09.2014 r., Zeszyt 39, s.121-124.

28 Zob. powołany wyżej wyrok TS z dnia 18 czerwca 2002 r. w sprawie C-289/99 Philips p. Remington Consumer Products Ltd., pkt 64, wyrok z dnia 7 lipca 2005 r. w sprawie C-353/03 Société des produits Nestlé SA p. Mars UK Ltd., pkt 26, wyrok z dnia 22 czerwca 2006 r., w sprawie C-24/05, Storck p. OHIM, pkt 67; w literaturze krajowej zamiast wielu U. Promińska, (w:) A. Nowicka, E. Nowińska, U. Promińska, Prawo własności przemysłowej, Warszawa 2005, s. 215; K. Szczepanowska-Kozłowska, (w:) System Prawa Prywatnego. Prawo własności przemysłowej t. XIV b, Warszawa 2012, s. 599; E. Wojcieszko-Głuszko, (w:) System Prawa Prywatnego. Prawo własności przemysłowej t. XIV b, Warszawa 2012, s. 459; P. Kostański, Ł. Żelechowski, Prawo własności przemysłowej, s. 306.

29 Według Naczelnego Sądu Administracyjnego (wyrok z dnia 8 listopada 2002 r., II SA 76/02) „samo wieloletnie używanie określonego znaku przez przedsiębiorcę nie wystarcza, by znak nabył wtórną zdolność odróżniania", „Monitor Prawniczy” 2003, nr 1, s. 5. Podobnie również powołany wyżej wyrok Sądu UE z dnia 25 września 2014 r. w sprawie T-474/12 Giorgio Giorgis p. OHIM, pkt 56 i powołane tam orzecznictwo. 
Wskazana przesłanka jest zrealizowana, jeżeli znak towarowych jest używany dla towarów zgłoszonych do rejestracji. Dlatego nie można skutecznie wykazywać nabycia zdolności odróżniającej poprzez używanie zarówno odmiany zgłoszonego znaku towarowego, jak i takiego samego znaku dla innych towarów, chociażby nawet podobnych. ${ }^{30}$

Znak towarowy może nabyć charakter odróżniający jedynie w przypadkach określonych w art. 129 ust. 2 pkt 1-3. Taka wykładnia pozwala zachować zgodność tej regulacji z dyrektywą. Wykluczone jest natomiast przezwyciężenie w drodze używania przeszkody rejestracji ustanowionej w art. 129 ust. 1 pkt 1, w myśl którego nie udziela się praw ochronnych na oznaczenia, które nie mogą być znakami towarowymi. Chodzi o oznaczenia nie spełniające warunków wymaganych do kwalifikacji jako znaku towarowego (art. 120 p.w.p.).

Przepis art. 131 p.w.p. wyłącza od rejestracji konkretnie wymienione kategorie oznaczeń. Ściślej biorąc, te oznaczenia mogą spełniać warunki znaku towarowego zdefiniowane w art. 120 ustawy. Jednakże art. 131 wyłącza wymienione oznaczenia od rejestracji jako znaki towarowe. ${ }^{31}$ Lege non distiguente nie ma możliwości ich rejestracji jako znaków towarowych. Nie ma zatem znaczenia, czy one uzyskały charakter odróżniający poprzez używanie, co wyjątkowo może jednak zdarzyć się w praktyce. To wyłączenie jest istotne również w kontekście art. 165 ust. 1 pkt 2 p.w.p., który odnosi się wyłącznie do oznaczeń wymienionych w art. 129 ustawy. ${ }^{32}$ Dlatego art. 165 ust. 1 pkt 2 expressis verbis nie może być stosowany do oznaczeń wymienionych w art. 131.

Używanie oznaczenia niezbędne do nabycia wtórnej zdolności odróżniającej musi odbywać się na terytorium Polski. Nie jest oczywiście wymagane równie intensywne używanie oznaczenia w każdym regionie. Nie wystarczy natomiast co do zasady używanie w innym państwie. W szczególności zgłaszający nie może powołać się skutecznie na art. $6 \mathrm{C}$ Konwencji paryskiej w celu uwzględnienia sytuacji na innych rynkach. Dotyczy to także znaków zgłoszonych w trybie międzynarodowej rejestracji. Nie można jednak wykluczyć, iż w dobie Internetu, telewizji satelitarnej i kablowej używanie transgraniczne może mieć pewne znaczenie, chociaż będzie to jednak marginalne znaczenie. W każdym przypadku wymagane jest bowiem używanie oznaczenia na terytorium Polski. ${ }^{33}$

Nie ma także znaczenia praktyka zagranicznych urzędów patentowych potwierdzających zdolność odróżniającą tego znaku towarowego. Istotna jest bowiem ocena

30 Zob. tak The Manual concerning proceedings before the Office, Part B, s. 40.

31 Zob. R. Skubisz, Funkcjonalność techniczna jako przeszkoda rejestracji znaku towarowego w prawie unijnym i prawie polskim, (w:) K. Szczepanowska-Kozłowska (red.), Oblicza prawa cywilnego. Księga jubileuszowa dedykowana Profesorowi Janowi Błeszyńskiemu, Warszawa 2013, s. 477 i n. Zob. także Ł. Żelechowski, Zdolność odróżniająca znaku towarowego - przegląd orzecznictwa Sądu Najwyższego i Naczelnego Sądu Administracyjnego z lat 2000-2004, „Glosa” 2005, nr 3, s. 93.

32 Zob. niżej uwagi w pkt $\mathrm{VI}$.

33 Zob. wyrok TS z dnia 7 września 2006 r. w sprawie C-108/05, Bovemij Verzekeringen NV p. Benelux-Merkenbureau, pkt 23. 
charakteru odróżniającego tego znaku towarowego w świetle domniemanej percepcji nabywców towarów pod tym znakiem na terytorium Polski. ${ }^{34}$

Charakter odróżniający może być uzyskany w szczególności podczas zwykłego zapoznawania się danego kręgu odbiorców ze znakiem. ${ }^{35}$ Przy ocenie, czy znak towarowy uzyskał charakter odróżniający w następstwie używania bierze się pod uwagę wszystkie sytuacje, w których odbiorcy towarów wchodzą w kontakt ze znakiem. Chodzi tutaj przede wszystkim o chwilę podejmowania decyzji o zakupie i jej wykorzystaniu, ale również może to być moment zapoznania się z reklamą lub chwilą konsumpcji towaru. ${ }^{36}$ Kluczowe znaczenie ma jednak moment podejmowania przez nabywcę decyzji o zakupie towaru. $\mathrm{W}$ tej bowiem chwili jest faktycznie urzeczywistniana najważniejsza zasada gospodarki rynkowej, jaką jest konkurencja przedsiębiorców. Nabywca wybierając (kupując) bowiem konkretny towar pod znakiem faktycznie wyróżnia ten produkt wśród wielu legitymujących się innym pochodzeniem.

Powstanie znajomości oznaczenia w obrocie, jego upowszechnienie, choćby nawet bardzo szerokie, nie może być jednak uważane w każdym przypadku za realizację przesłanki używania w charakterze znaku towarowego. Oznaczenie może bowiem być znane jako nazwa produktu (usługi) lub jako określenie jednej z wielu cech towarów (np. wskazanie na pochodzenie produktu z określonego obszaru geograficznego). Dlatego przykładowo skutkiem intensywnej reklamy może być jedynie upowszechnianie określonego oznaczenia jako informacji o pewnej właściwości towaru (np. o jego pochodzeniu geograficznym, o jego zastosowaniu, składzie). Tak więc, utożsamianie znajomości określonego oznaczenia używanego w związku z towarem wśród jego odbiorców z używaniem jako znaku towarowego jest zasadniczym błędem metodologicznym. Skutkiem braku właściwego rozróżnienia pomiędzy znajomością oznaczenia jako określenia rodzajowego lub opisowego a jego postrzeganiem jako znaku towarowego jest udzielanie albo utrzymywanie w sposób bezzasadny prawa ochronnego na takie oznaczenia. Może to prowadzić także do błędnej kwalifikacji zachowania pozwanego jako naruszającego prawo ochronne na znak towarowy.

Znak towarowy może nabyć charakter odróżniający jako całość. Może jednak nabyć taki charakter, także w razie jego używania jako część innego, zarejestrowanego znaku towarowego lub używanie go jako odrębnego oznaczenia w połączeniu z zarejestrowanym znakiem towarowym. ${ }^{37}$ Nie jest bowiem bezwzględnie konieczne, aby znak towarowy był używany samodzielnie. Są to jednak, jak poka-

\footnotetext{
34 Zob. odpowiednio wyrok TS z dnia 12 lutego 2004 r. w sprawie C-218/07 Henkel, pkt 65, (w:) R. Skubisz (red.), Własność przemysłowa..., op. cit., poz. 25.

35 Zob. zamiast wielu wyrok TS z dnia 6 maja 2003 r. w sprawie C-244/03, Libertel, pkt 67, (w:) R. Skubisz (red.), Własność przemysłowa..., op. cit., poz. 18.

36 Zob. powołany wyżej wyrok TS z dnia 22 czerwca 2006 r., w sprawie C-24/05P August Storck, pkt 70 i 71.

37 Zob. powołany wyżej wyrok z dnia 7 lipca 2005 r. w sprawie C-353/03 Nestle, pkt 27 i 30; wyrok TS z dnia 9 marca 2007 w sprawie C-245/06P Saiwa Spa p. OHIM, pkt 43, www.curia.europa.eu (data dostępu: 11.09.2015 r.).
} 
Uzyskanie charakteru odróżniającego przez znak towarowy poprzez używanie...

zuje praktyka, przypadki wyjątkowe. Oczywiście muszą wtedy być spełnione, w odniesieniu do tego znaku, wszystkie wyżej wymienione warunki. Przeciętny odbiorca powinien bowiem także w tym przypadku odróżnić dane oznaczenie jako odrębne od towaru (opakowania) i innych oznaczeń na towarze (opakowaniu) oraz postrzegać je jako wyłączną wskazówkę o pochodzeniu komercyjnym konkretnego towaru.

\section{Miarodajna data nabycia wtórnej zdolności odróżniającej}

Przepis art. 130 p.w.p. expressis verbis określa datę zgłoszenia znaku w Urzędzie Patentowym jako datę właściwą dla ustalenia zdolności odróżniającej. Mając jednak na uwadze art. 123 ustawy należy także uwzględnić datę zgłoszenia znaku towarowego w zagranicznym urzędzie patentowym państwa członkowskiego konwencji paryskiej (pierwszeństwo konwencyjne) lub zgłoszenia, wystawienia na międzynarodowej wystawie (pierwszeństwo z wystawienia). W tych dwóch przypadkach, w praktyce raczej niezbyt częstych, data pierwszeństwa będzie wcześniejsza niż data zgłoszenia znaku towarowego w Urzędzie Patentowym. Ponieważ data zgłoszenia w Urzędzie Patentowym również konstytuuje pierwszeństwo (pierwszeństwo zwy$\mathrm{kłe),} \mathrm{to} \mathrm{ściśle} \mathrm{biorąc} \mathrm{podstawą} \mathrm{oceny,} \mathrm{zgodnie} \mathrm{z} \mathrm{powołanymi} \mathrm{przepisami,} \mathrm{jest} \mathrm{data}$ pierwszeństwa znaku towarowego. Skoro jednak przepis art. 130 odnosi ocenę dostatecznych znamion odróżniających literalnie do daty zgłoszenia, to poniżej, z zastrzeżeniem regulacji art. 123, również jest używane to określenie. Prawidłowo należałoby jednak mówić o dacie pierwszeństwa jako dacie, która ustala podstawę oceny zdolności odróżniającej. ${ }^{38}$ Ta data bowiem w prawie polskim wyznacza kryterium właściwe do określenia zdolności odróżniającej znaku towarowego. Dotyczy to zarówno postępowania o udzieleniu prawa ochronnego, jak i unieważnienia tego prawa (art. 164 w zw. z art. 130). Jest to data, w której zgłoszony do rejestracji znak towarowy powinien najpóźniej legitymować się charakterem odróżniającym.

W świetle literalnej wykładni tego przepisu nabycie przez oznaczenie zdolności odróżniającej po dacie zgłoszenia, nie może uzasadniać udzielenia przez Urząd Patentowy prawa ochronnego na znak towarowy. Przy zastosowaniu dosłownej interpretacji tego przepisu nie ma zatem znaczenia, czy oznaczenie nabyło charakter odróżniający bezpośrednio po zgłoszeniu (w toku postępowania o udzielenie prawa ochronnego), czy też już po udzieleniu prawa ochronnego. Brak dostatecznych znamion odróżniających, najpóźniej w dacie zgłoszenia, jako bezwzględna przeszkoda rejestracji, stanowi podstawę unieważnienia prawa ochronnego, choćby znak w okresie późniejszym, wskutek używania nabył takie cechy. 
Wyjaśnienia wymaga użycie określenie „,w szczególności” w art. 130 ustawy. To określenie nie może być uważane za dozwolenie ustawodawcy na przesuwanie daty stanowiącej podstawę oceny zdolności odróżniającej (np. do daty rejestracji). Ustawodawca w ten sposób wyraził bowiem swoją wolę oceny charakteru odróżniającego na datę zgłoszenia, ale jednocześnie zaznaczył odstępstwa od tej podstawowej zasady, które to odstępstwo w bardzo wąskim zakresie jest zrealizowane jedynie w art. 165 ust. 1 pkt ustawy. ${ }^{39}$

W świetle powyższego, data zgłoszenia ma bezwzględnie podstawowe znaczenie dla określenia każdej zdolności odróżniającej, w tym nabycia charakteru odróżniającego poprzez używanie oznaczenia w obrocie gospodarczym. ${ }^{40}$ Dlatego w razie zgłoszenia znaku, który nie ma zdolności odróżniającej w tej dacie, Urząd Patentowy powinien wydać decyzję o odmowie udzielenia prawa ochronnego na zgłoszony znak towarowy. Również w sytuacji, gdy znak został zarejestrowany, to w postępowaniu o unieważnienie prawa ochronnego ocena charakteru odróżniającego znaku towarowego następuje także na dzień zgłoszenia znaku w Urzędzie Patentowym.

Powyższa wykładnia art. 130 zapewnia spójność systemu bezwzględnych i względnych podstaw odmowy rejestracji w dziedzinie znaków towarowych, ponieważ data zgłoszenia znaku towarowego określa jego pierwszeństwo i rozstrzyga kolizję z innymi znakami. ${ }^{41}$ Nie można bowiem przeoczyć, iż prawo jest udzielone po pewnym czasie od daty zgłoszenia, ale ze skutkiem od daty zgłoszenia. Ta interpretacja art. 130 uniemożliwia zgłaszającemu wykorzystanie czasu postępowania rejestracyjnego w celu udowodnienia, iż jego znak uzyskał charakter odróżniający po zgłoszeniu do rejestracji. Odmienna wykładnia prowadziłaby do uprzywilejowania zgłaszających znaki towarowe pozbawione zdolności odróżniającej, które po jej uzyskaniu w okresie późniejszym mogłyby legitymować się wcześniejszym pierwszeństwem w stosunku do znaków towarowych, wyposażonych w dacie zgłoszenia (pierwszeństwa) zdolnością odróżniającą. ${ }^{42}$

Jeżeli znak towarowy jest zarejestrowany, a nie ma charakteru odróżniającego, osoby trzecie mogą wystąpić do Urzędu Patentowego ze sprzeciwem wobec rejestracji znaku towarowego, ewentualnie z wnioskiem o unieważnienie prawa ochronnego. Taki charakter może jednak nabyć również znak towarowy po dacie zgłoszenia, jak również po dacie rejestracji (art. 165 ust. 1 pkt 2 ustawy). ${ }^{43} \mathrm{~W}$ tym przypadku, jak

39 Zob. niżej pkt VI.

40 Zob. także K. Szczepanowska-Kozłowska, (w:) System Prawa Prywatnego. Prawo własności przemysłowej, s. 599; P. Kostański, Ł. Żelechowski, Prawo własności przemysłowej, op. cit., s. 306; U. Promińska, (w:) E. Nowińska, U. Promińska, M. du Vall, Prawo własności przemysłowej, Warszawa 2014, s. 426; odmiennie W. Włodarczyk, Zdolność odróżniająca znaku towarowego, Lublin 2001, s. 232-233 i M. Andrzejewski, (w:) P. Kostański (red.), Prawo własności przemysłowej, Komentarz, Warszawa 2014, s. 814.

41 Tak Trybunał Sprawiedliwości, na tle art. 7 ust. 3 rozporządzenia nr 207/2009, w wyroku z dnia 11 czerwca 2009 r. w sprawie C-542/07P, Imagination Technologies Ltd pko OHIM, pkt 51, www.curia.europa.eu (data dostępu: 11.09.2015 r.). Ta teza była następnie wielokrotnie powtarzana przez Trybunał.

42 Zob. powołany wyżej wyrok Trybunału Sprawiedliwości z dnia 11 czerwca 2009 r. w sprawie C-542/07P, Imagination Technologies Ltd pko OHIM, pkt 52.

43 Zob. w kwestii znaczenia art. 165 ust. 1 pkt 2 uwagi w pkt VI poniżej. 
Uzyskanie charakteru odróżniającego przez znak towarowy poprzez używanie...

zdaje się wynikać z tego przepisu, data zgłoszenia (pierwszeństwa) nie stanowi podstawy oceny zdolności odróżniającej znaku towarowego. Jednakże norma art. 165 ust. 1 pkt 2 ma charakter wyjątkowy, ponieważ zawiera odstępstwo od ustawowych warunków wymaganych dla uzyskania prawa (art. 164 zw. z art. 130). Charakter wyjątkowy normy art. 165 ust. 1 pkt 2 ma zasadnicze znaczenie dla interpretacji tego przepisu. Przepis ten powinien być przedmiotem ścisłej wykładni.

\section{Dowody nabycia zdolności odróżniającej poprzez używanie; ciężar dowodu}

Zgłaszający znak towarowy może wykazać nabycie wtórnej zdolności odróżniającej znaku towarowego poprzez przedstawienie odpowiednich dowodów. Dowody te powinien zgłaszający zaoferować w postępowaniu zgłoszeniowym, jeżeli Urząd Patentowy zakwestionuje istnienie samoistnego charakteru odróżniającego znaku towarowego w dacie zgłoszenia. W toku postępowania o unieważnienie prawa ochronnego na znak towarowy Uprawniony ma również możliwość przedstawienia takich dowodów. Chodzi o te wszystkie przypadki, gdy w toku postępowania o unieważnienie prawa ochronnego wnioskodawca powołuje się na brak charakteru odróżniającego w dacie zgłoszenia znaku towarowego do Urzędu Patentowego.

W każdej z tych dwóch sytuacji, zgłaszający znak towarowy w toku postępowania o udzielenie prawa, bądź uprawniony z tytułu rejestracji znaku, w toku postępowania o unieważnienie, w celu wykazania charakteru odróżniającego poprzez używanie może przedstawić, w gruncie rzeczy, takie same dowody. Przepisy prawa nie różnicują bowiem środków dowodowych w zależności od postępowania, w którym powstał problem wykazania charakteru odróżniającego nabytego poprzez używanie znaku. Dlatego podstawowe znaczenie praktyczne ma ustalenie dowodów, jakie mogą być przedstawione w celu wykazania tej zdolności i ich ocena. Ściśle biorąc, zagadnienia dowodów jako materia proceduralna, zgodnie z zasadą autonomii proceduralnej obowiązującej w prawie unijnym, podlega prawu krajowemu, chyba że Trybunał Sprawiedliwości w konkretnej kwestii zajął stanowisko w trybie prejudycjalnym. Taki przypadek dotyczy dowodów na uzyskanie wtórnej zdolności odróżniającej poprzez używanie znaku towarowego.

Trybunał Sprawiedliwości w wyroku w sprawie Chiemsee wyraził następujący pogląd w kwestii okoliczności odnoszących się do nabycia charakteru odróżniającego poprzez używanie oznaczenia. Według Trybunału w celu ustalenia, czy znak towarowy uzyskał charakter odróżniający w następstwie używania, właściwy organ musi dokonać całościowej oceny dowodów mogących wykazać, że znak towarowy stał się zdolny do identyfikowania danego towaru jako pochodzącego z określonego przedsiębiorstwa a zatem do odróżniania tego towaru od towarów innych przedsię- 
biorstw. ${ }^{44}$ I dalej Trybunał podnosi, iż należy uwzględnić takie okoliczności, które wskazują na ,udział znaku w rynku; intensywność, zasięg geograficzny i długotrwałość używania znaku; kwotę zainwestowana przez przedsiębiorstwo w promocję znaku; odsetek osób danej kategorii, które, ze względu na znak, identyfikują towary jako pochodzące z konkretnego przedsiębiorstwa; a także oświadczenia stosownych izb handlowo-przemysłowych oraz innych stowarzyszeń handlowych i zawodowych". ${ }^{45}$ Trybunał zaakcentował zatem dyrektywę całościowej oceny dowodów i wymienił rozmaite fakty (np. udział w rynku, wydatki na reklamę) także środki dowodowe (np. oświadczenia izb handlowych). Jak wynika ze stanowiska Trybunału powyższe wyliczenie okoliczności (faktów) istotnych w toku oceny nabycia wtórnej zdolności odróżniającej ma charakter jedynie przykładowy. Nie jest zatem wykluczone uwzględnienie także innych okoliczności. Wszystkie one powinny być wykazane w toku postępowania za pomocą przedstawionych dowodów. Środkami dowodowym mogą być katalogi, ulotki reklamowe, gazetki, plakaty, tablice reklamowe, nośniki reklamy telewizyjnej, radiowej, internetowej, a także raporty instytutów zajmujących się badaniem sytuacji na rynku, oświadczenia stowarzyszeń zawodowych, wyniki badań sondażowych opinii konsumentów, dane sprzedażowe, informacje o nakładach reklamowych, oświadczenia poszczególnych osób itp. Dowodem może być zatem każdy środek, który wskazuje na używanie i rozpoznawanie oznaczenia jako znaku towarowego w obrocie przez znaczącą część nabywców tych towarów. W toku postępowania są również niekiedy przez stronę przedstawiane opinie prawników, socjologów, psychologów, a nawet odpowiednich instytucji naukowo-badawczych. Ich wartość dowodowa jest bardzo ograniczona. Wydaje się, iż należy je traktować raczej za stanowisko strony.

Środki dowodowe, przydatne w toku wykazywania wtórnej zdolności odróżniającej, nie są jednak równoważne wobec siebie. Orzecznictwo sądów unijnych wyróżnia bowiem wśród tych dowodów dwie kategorie: bezpośrednie i pośrednie (wtórne). Bezpośrednim dowodem o charakterze empirycznym są wyniki badania opinii publicznej oraz opinie branżowych stowarzyszeń i izb handlowo-przemysłowych. Do pośrednich należą informacje o wysokości udziału w rynku, nakładach na reklamę itd. Są to dane, które pozwalają na ustalenie zakresu, czasu oraz intensywności używania znaku towarowego.

Istotne znaczenie $\mathrm{w}$ praktyce ma ocena wszystkich dowodów przedstawianych w celu wykazania nabycia wtórnej zdolności odróżniającej. Sądy unijne wypracowały już szereg konkretnych zasad dotyczących tej oceny. ${ }^{46}$ Przede wszystkim

44 Zob. wyżej powołany wyrok TS z dnia 4 maja 1999 r., w sprawie C-109/97, Windsurfing Chiemsee, pkt 49.

45 Zob. wyżej powołany wyrok TS z dnia 4 maja 1999 r., w sprawie C-109/97, Windsurfing Chiemsee, pkt 51.

46 W kwestii dowodów zamiast wielu powołany wyżej wyrok z dnia 19 czerwca 2014 r., w sprawach połączonych C-217/12 i 218/13 Oberbank AG (C-217/13) Banco Santander S.A. (C-218/13), Santander Consumer Bank (C-218/13) Santander Consumerbank AG p. Deutscher Sparkassen- und Giroverband e.V., pkt 41-49, wyrok Sądu UE z dnia 29 stycznia 2013 r., w sprawie T-25/11, Germans Boada p. OHIM, pkt 72-90 i przytoczone tam orzecznictwo. 
uzyskania charakteru odróżniającego nie mogą definitywnie dowodzić ogólne i abstrakcyjne dane, takie jak udziały procentowe w rynku. ${ }^{47}$ Określony odsetek osób dotyczący poziomu rozpoznawalności znaku. ${ }^{48}$ Takie dane nie przesądzają bowiem definitywnie, że krąg odbiorców tych towarów postrzega oznaczenie jako wskazówkę o ich pochodzeniu komercyjnym. Takie informacje mogą bowiem dowodzić jedynie faktu odczytania przez potencjalnych nabywców oznaczenia jako informacji o właściwości towaru (produktu). To samo dotyczy odpowiednio wielkości sprzedaży towarów, jak również nakładów na ich reklamę. ${ }^{49}$ Przedstawiane dowody powinny dotyczyć okresu najpóźniej na dzień zgłoszenia (pierwszeństwa) znaku towarowego do Urzędu Patentowego. Odwołanie się do okoliczności późniejszych, co do zasady, nie może być zaakceptowane w świetle regulacji późniejszych. Wyjątek dotyczy sytuacji, gdy takie dowody pozwalają na ustalenie sytuacji na dzień zgłoszenia znaku towarowego. ${ }^{50}$

Szczególnej oceny wymagają wyniki badań opinii publicznej. Trybunał Sprawiedliwości wyraża dla nich aprobatę jednak z dużą ostrożnością. ${ }^{51} \mathrm{~W}$ bardzo wielu państwach członkowskich Unii Europejskiej badania sondażowe nie odgrywają jakiejkolwiek roli lub są oceniane bardzo sceptycznie. Faktycznie największe znaczenie mają jedynie w praktyce sądów niemieckich. ${ }^{52}$ Co się tyczy polskiej praktyki

47 Zob. zamiast wielu powołany wyżej wyrok TS z dnia 4 maja 1999 r. w sprawie C-109/97 Windsurfing Chiemsee, pkt 52.

48 Zob. powołany wyżej wyrok TS z dnia 19 czerwca 2014 r. w sprawach połączonych C-217/12 i 218/13 Oberbank AG (C-217/13) Banco Santander S.A. (C-218/13), Santander Consumer Bank (C-218/13) Santander Consumerbank AG p. Deutscher Sparkassen- und Giroverband e.V., pkt 48 i 49, www.curia.europa.eu (data dostępu: 11.09.2015 r.).

49 Zob. wyrok Sądu z dnia 6 lipca 2011 r., w sprawie T-318/09 Audi AG, Volkswagen AG p. OHIM, pkt 64 i 65 oraz cytowane tam orzecznictwo. Ilustrację tego stanowiska zawarł Sąd UE w wyroku z dnia 29 września 2010 r. w sprawie T-378/07 CNH Global NV p. OHIM, w którym stwierdził, co następuje: „Co się tyczy w drugiej kolejności wielkości sprzedaży i materiału reklamowego, należy wyjaśnić że zgodnie z orzecznictwem są to dowody wtórne, które ewentualnie mogą stanowić poparcie dla bezpośrednich dowodów uzyskania charakteru odróżniającego w następstwie używania, takich jak dowody wynikające ze wspomnianych oświadczeń. Wielkość sprzedaży i materiał reklamowy jako takie nie wskazują bowiem na to, że krąg odbiorców, do którego skierowane są rozpatrywane towary, postrzega oznaczenie jako wskazanie pochodzenia handlowego. Z tego względu, jeżeli chodzi o państwa członkowskie, w odniesieniu do których nie przedstawiono żadnych innych dowodów, samo wskazanie na wielkość sprzedaży i materiał reklamowy nie może dowodzić uzyskania charakteru odróżniającego w następstwie używania (zob. podobnie ww. wyrok w sprawie Struktura szklanej powierzchni, pkt 41)”, pkt 54, www. curia.europa.eu (data dostępu: 11.09.2015 r.).

50 Zob. wyrok TS z 19.06.2014 r. w sprawach połączonych C-217/13 i C-218/13 Oberbank AG (C-217/13), Banco Santander S.A. (C-218/13), Santander Consumer Bank (C-218/13), Santander Consumerbank AG p. Deutscher Sparkassen- und Giroverband e.V., pkt 60 i powołane tam orzecznictwo, www.curia.europa.eu (data dostępu: ...).

51 Zob. powołany wyżej wyrok z dnia 4 maja 1999 r. w sprawie C-109/97 Windsurfing Chiemsee, w którym Trybunał stwierdził ,jeżeli chodzi o metodę, która ma być użyta do oceny zdolności odróżniającej znaku, w związku z którym wnosi się o rejestrację, prawo wspólnotowe nie zabrania właściwemu organowi, który napotyka szczególne trudności w tym względzie (podkreślenie autora), odwołanie się do sondażu opinii publicznej, jako wytycznych dla wydania przezeń wyroku", pkt 53. To bardzo ostrożne stanowisko w kwestii znaczenia badań sondażowych potwierdził Trybunał w wyroku z dnia 19 czerwca 2014 r. w sprawach C-217/13 i C-218/13 Oberbank i inni. Według Trybunału „nawet gdy wyniki badania opinii mogą (podkreślenie autora) stanowić część elementów pozwalających na ocenę, czy taki znak towarowy uzyskał charakter odróżniający w następstwie używania, wynik takich badań opinii nie może stanowić jedynego (podkreślenie autora) determinującego elementu pozwalającego na wniosek co do istnienia charakteru odróżniającego uzyskanego w następstwie używania" pkt 48.

52 Zob. w tej sprawie A. v. Mühlendal, Verkehrsdurchsetzung in der Rechtsprechung des EuGH Anmerkungen zu EuGH, Urt. V. 19.6.2014 - C-217/13 - Oberbank na/DSGV, GRUR, 2014, Nr 11, s. 1045. 
największą przydatność powinny mieć badania sondażowe, które zostały przeprowadzone, po wcześniejszej akceptacji metodyki badania, na zlecenie Urzędu Patentowego lub sądów. Jeżeli natomiast zostały przedstawione przez stronę, to mogą być brane pod uwagę jedynie wtedy, z uwzględnieniem przytoczonego stanowiska Trybunału Sprawiedliwości, gdy ich poprawność metodyczna i treściowa nie wywołuje jakichkolwiek zastrzeżeń.

Przedstawione przez stronę dowody podlegają ocenie organu orzekającego (Urzędu Patentowego lub sądu). Te organy, biorąc pod uwagę okoliczności stanu faktycznego mogą przypisywać zróżnicowane znaczenie poszczególnym dowodom. W każdym przypadku powinny jednak zmierzać do określenia poglądu przeciętnego nabywcy towaru co do wyodrębnienia określonego oznaczenia i jego postrzegania jako wskazówki o komercyjnym pochodzeniu towaru.

Pośrednie dowody nie przesądzają o nabyciu charakteru odróżniającego przez używanie, gdy „oznaczenie pozbawione samoistnego charakteru odróżniającego występuje zawsze wraz z innymi znakami towarowymi - w odróżnieniu od niego posiadającymi taki charakter...". ${ }^{53}$ Takie oznaczenie może wprawdzie także nabyć charakter odróżniający poprzez używanie, ale są potrzebne inne dowody, które pozwolą na ustalenie, iż przeciętny nabywca postrzega to oznaczenie jako odrębne od innych znaków i informacji na towarze i jako wskazówkę o pochodzeniu tych towarów.

Praktyczne znaczenie ma zagadnienie, kogo obciąża obowiązek wykazania, iż oznaczenie uzyskało charakter odróżniający w następstwie używania. W gruncie rzeczy chodzi o dwie sytuacje: w postępowaniu o udzielenie prawa ochronnego oraz w postępowaniu o jego unieważnienie. W obydwu tych postępowaniach ciężar dowodu obciąża zgłaszającego bądź uprawnionego z tytułu rejestracji. W pierwszym przypadku, jeżeli Urząd Patentowy zgłosi zastrzeżenia w przedmiocie charakteru odróżniającego, to zgłaszający powinien podjąć próbę wykazania, iż zgłaszający znak towarowy ma samoistny charakter odróżniający lub wystąpić z tezą, iż nabył charakter odróżniający poprzez używanie i przedstawić odpowiednie dowody na poparcie swojego twierdzenia. W drugim przypadku, w postępowaniu o unieważnienie prawa ochronnego, również uprawniony powinien przeprowadzić taki dowód. ${ }^{54}$

W tych dwóch sytuacjach obowiązek przeprowadzenia dowodu nabycia wtórnej zdolności odróżniającej obciąża zatem zgłaszającego bądź uprawnionego z tytułu rejestracji znaku towarowego.

Powyższe zasady stosuje się w pełni do postępowania przed Urzędem Patentowym i sądami administracyjnymi. Dowody na nabycie charakteru odróżniającego poprzez używanie znaku towarowego powinny być przedstawione w postępowaniu przed organem administracyjnym. W szczególności art. $106 \S 3$ prawa o postępo-

53 Zob. powołany wyżej wyrok z dnia 6 lipca 2011 r. w sprawie T-318/09 Audi AG, pkt 73 i wskazane tam orzecznictwo.

54 Zob. w kwestii ciężaru dowodu powołany wyżej wyrok TS z dnia 19 czerwca 2014 r., w połączonych sprawach C-217/12 i C-218/13 Oberbank, pkt 62-74 i powołane tam obszernie orzecznictwo. 
Uzyskanie charakteru odróżniającego przez znak towarowy poprzez używanie...

waniu przed sądami administracyjnymi ${ }^{55}$,nie może być podstawą żądania przeprowadzenia przed sądem administracyjnym postępowania dowodowego wskazującego na istnienie nowych okoliczności faktycznych, których strona nie podniosła w toku postępowania przed organem administracyjnym". ${ }^{56}$ Celem art. $106 \S 3$ powołanej ustawy ,nie jest ponowne ustalenie stanu faktycznego sprawy administracyjnej, lecz ocena, czy właściwe w sprawie organy ustaliły ten stan zgodnie z regułami procedury, a następnie, czy prawidłowo zastosowały przepisy prawa materialnego do poczynionych ustaleń", 57

\section{Problem zastosowania art. 165 ust. 1 pkt 2 p.w.p.}

Przepis art. 165 ust. 1 pkt 2 p.w.p. stanowi, iż ,z wnioskiem o unieważnienie prawa ochronnego nie można wystąpić po upływie pięciu lat od udzielenia prawa ochronnego, jeżeli prawo to udzielone zostało z naruszeniem przepisów art. 129, lecz znak w wyniku używania nabrał charakteru odróżniającego”. Treść tego przepisu pozwala ustalić następujące przesłanki jego zastosowania.

Przede wszystkim przepis art. 165 ust. 1 pkt 2 odnosi się do wszystkich przypadków braku „charakteru odróżniającego”, o których stanowi art. 129 tej ustawy. Przepis ten nie dotyczy natomiast innych przeszkód rejestracji znaku towarowego. Dlatego nie można skutecznie w postępowaniu o unieważnienie prawa ochronnego powoływać się na przepis art. 165 ust. 1 pkt 2 w odniesieniu do innych przeszkód rejestracji niż brak charakteru odróżniającego.

Fakt, iż przepis art. 165 ust. 1 wymienia art. 129 należy również rozumieć w ten sposób, iż stosuje się on jedynie do znaków zgłoszonych pod rządami ustawy prawo własności przemysłowej, tj. 22 sierpnia 2001 r. i później. Odmienny pogląd, w myśl którego art. 165 ust. 1 pkt 2 należy stosować także do znaków towarowych zarejestrowanych na podstawie ustawy z 1985 r. o znakach towarowych, ${ }^{58}$ byłby sprzeczny nie tylko z brzmieniem tego przepisu, ale także z art. 315 ust. 3 zd. 1 p.w.p. Przepis art. 315 ust. 3 zd. 2 jako normę wyjątkową w stosunku do regulacji w zd. 2 tego przepisu przewiduje stosowanie art. 37 ust. 2 nowej ustawy jedynie do wynalazków, do wzorów użytkowych nakazuje stosowanie przepisów nowej ustawy. Przepis ten nie przewiduje natomiast odmiennej rejestracji w zakresie zdolności odróżniającej.

Wniosek o unieważnienie prawa ochronnego podlega oddaleniu, jeżeli został złożony po upływie pięciu lat od daty udzielenia tego prawa, a znak towarowy uzyskał charakter odróżniający. Jeżeli znak towarowy uzyskał wprawdzie charakter odróżniający po dacie zgłoszenia, ale nie upłynął okres pięciu lat od daty rejestracji,

\footnotetext{
55 Ustawa z dnia 30 sierpnia 2002 r. Prawo o postępowaniu przed sądami administracyjnymi (Dz.U. 2012, poz. 270).

56 Zob. wyrok WSA w Łodzi z 6.11.2013 r. I SA/Łd 369/13, www.nsa.gov.pl (data dostępu: 11.09.2015 r.).

57 Zob. wyrok WSA w Opolu z 11.7.2013 r., II SA/Op 97/13, www.nsa.gov.pl (data dostępu: 11.09.2015 r.).

58 Dz.U. z 1985 r. Nr 5, poz. 17.
} 
to ten wniosek powinien być skuteczny. W świetle tego przepisu nie ma znaczenia, czy znak pozbawiony samoistnego charakteru odróżniającego uzyskał zdolność odróżniania jeszcze przed datą rejestracji, czy też już po tej dacie. Wniosek o unieważnienie podlega oddaleniu nawet w tym przypadku, gdy znak nabył charakter odróżniający po upływie pięciu lat, jeżeli tylko stało się to przed datą złożenia wniosku.

Lektura tego przepisu prowadzi do wniosku, iż jest to norma wyjątkowa, która pozwala zachować, w świetle dosłownej wykładni, po spełnieniu przewidzianych warunków, prawo ochronne na znak towarowy, pomimo iż ten znak nie legitymował się w dacie zgłoszenia zdolnością odróżniającą. Niewątpliwie ratio legis tego przepisu należy upatrywać w fakcie, iż uprawniony mógł po dacie rejestracji poczynić nakłady, które oznaczenie opisowe lub rodzajowe zmieniły w wyposażone w zdolność odróżniającą. Jednakże ten przepis niewątpliwie zakłóca spójność bezwzględnych i względnych przeszkód rejestracji. Respektuje bowiem interesy uprawnionego $\mathrm{z}$ rejestracji takiego znaku towarowego kosztem osoby uprawnionej do kolizyjnego znaku, której znak w dacie zgłoszenia (pierwszeństwa) charakteryzował się charakterem odróżniającym.

$Z$ treści art. 165 ust. 1 pkt 2 zdaje się wynikać, iż w tym przepisie ustawodawca przeprowadził transpozycję art. 3 ust. 3 zd. 2 dyrektywy do prawa polskiego. $Z$ całości art. 165 ust. 1 wynika jednak, iż ustawodawca dokonał połączenia art. 3 ust. 3 zd. 2 i art. 9 dyrektywy (tolerowanie używania znaku towarowego bez zgody uprawnionego przez okres pięciu lat). Takie rozwiązanie nie występuje w legislacji innych państw członkowskich Unii Europejskiej. Połączenie implementacji art. 3 ust. 3 zd. 2 i art. 9 dyrektywy budzi zasadnicze wątpliwości w świetle odmiennego ratio legis tych przepisów. ${ }^{59}$

Jak już wyżej wskazano, przepis art. 3 ust. 3 zd. 2 zawiera normę fakultatywną, co ma taki skutek, iż ustawodawca krajowy nie jest obowiązany implementować tej ustawy do swojego krajowego porządku prawnego, ale jeżeli już decyduje się na taki zabieg, to powinien przenieść normę dyrektywy w jej dosłownym brzmieniu. Zapoznanie się z ustawami innych państw członkowskich Unii Europejskiej pozwala na stwierdzenie, iż większość tych państw nie skorzystała z normy art. 3 ust. 3 zd. 2 dyrektywy. Natomiast brak ograniczenia czasowego w krajach, które taką normę wprowadziły do swojego prawa.

W tym kontekście szczególnego znaczenia nabiera zagadnienie zgodności art. 165 ust. 1 pkt 2 z prawem unijnym. Polski ustawodawca dopuszcza wprawdzie możliwość nabycia charakteru odróżniającego przez znak towarowy po dacie zgłoszenia lub rejestracji, ale wyłącza skuteczne wystąpienie z wnioskiem o unieważnienie w okresie pięciu lat od daty rejestracji. Uzyskanie charakteru odróżniającego 
przez oznaczenie w następstwie używania jest zatem możliwe po upływie kilku lat. W praktyce ten okres może wynosić ponad siedem lat (co najmniej dwa lata postępowania o udzielenie prawa ochronnego i pięć lat od daty rejestracji). Wynika $\mathrm{z}$ tego, iż polski ustawodawca nie implementował prawidłowo fakultatywną normę art. 3 ust. 3 zd. 2 dyrektywy. Ustanowił bowiem pięcioletni okres, nieprzewidziany w dyrektywie, jako dodatkową przesłankę nabycia charakteru odróżniającego dla oznaczeń pozbawionych takiej właściwości w dacie zgłoszenia. Na tym tle powstaje zatem pytanie, czy taka zmiana normy fakultatywnej dyrektywy przez ustawodawcę krajowego uzasadnia zarzut sprzeczności z regulacją unijną, a w razie odpowiedzi twierdzącej, jakie skutki z tego wynikają dla osoby uprawnionej z rejestracji i osób trzecich (np. pozwanego w postępowaniu o naruszenie ${ }^{60}$ ).

Przede wszystkim należy ponownie zauważyć, iż ustawodawca krajowy transponując do prawa krajowego normę fakultatywną może jedynie przyjąć normę o takiej samej treści bądź nie uczynić tego. Nie może jednak zmieniać treści normy fakultatywnej. ${ }^{61}$ Nie ulega zatem wątpliwości, iż występuje sprzeczność pomiędzy normą art. 3 ust. 3 zd. 2 dyrektywy a art. 165 ust. 1 pkt 2 ustawy. Tej sprzeczności nie można wyeliminować za pomocą interpretacji art. 165 ust. 1 pkt 2, które zapewnią zgodność tej normy ze wskazaną regulacją dyrektywy. Przeszkodą jest jednoznaczne brzmienie art. 165 ust. 1 pkt 2 ustawy w zakresie ustanowienia dodatkowej przesłanki - 5-letniego okresu nabycia zdolności odróżniającej poprzez używanie.

Wykluczenie wykładni prounijnej w celu zapewnienia zgodności prawa polskiego z prawem unijnym nakazuje rozważyć pominięcie art. 165 ust. 1 pkt 2 ustawy i stosowanie bezpośrednio normy art. 3 ust. 3 zd. 2. Ta możliwość zakłada, iż ustawodawca zdecydował się na wprowadzenie do swojego porządku prawnego normy fakultatywnej, ale skoro uczynił to nieprawidłowo, to stosuje się bezpośrednio dyskutowaną normę dyrektywy. W rezultacie należałoby przyjąć, iż nie obowiązuje już jakikolwiek termin dla nabycia wtórnej zdolności odróżniającej. Dyskutowana możliwość zapewnienia zgodności prawa polskiego z prawem unijnym ma u swoich podstaw założenie, iż norma art. 3 ust. 3 zd. 2 nadaje się do bezpośredniego stosowania oraz normy fakultatywne dyrektywy w stosunkach wertykalnych mogą być bezpośrednio stosowane, jeżeli ustawodawca krajowy wyraził wolę, chociaż w sposób nieprawidłowy przecięcia do prawa krajowego normy fakultatywnej dyrektywy. Kwestia ta nie jest dotąd wyjaśniona w orzecznictwie Trybunału Sprawiedliwości. Wydaje się jednak, iż taka możliwość nie wchodzi w rachubę w świetle orzecznictwa Trybunału Sprawiedliwości. Ewentualne wątpliwości dotyczące takiej

60 Zob. w kwestii rozwiązywania sprzeczności normy prawa krajowego z normą prawa unijnego zamiast wielu R. Skubisz, Roszczenie o udzielenie informacji w prawie własności przemysłowej (w świetle dyrektywy nr 2004/48 i prawa polskiego), (w:) Aurea Praxis Aurea Theoria, Księga Pamiątkowa ku czci Profesora Tadeusza Erecińskiego, Warszawa 2011, s. 2565 i n. i powołane tam orzecznictwo. Zob. P. Brzeziński, Stosowanie pozytywne i negatywne dyrektywy unijnej pomiędzy podmiotami prywatnymi, „Europejski Przegląd Sądowy” 2010, nr 8, s. 11-18.

Zob. wyżej uwagi w pkt 1. 
interpretacji art. 3 ust. 3 zd. 2 uzasadniałyby skierowanie przez polski sąd pytania prejudycjalnego do Trybunału Sprawiedliwości.

Możliwa jest także jeszcze inna interpretacja. Przepis art. 165 ust. 1 pkt 2 jest normą obowiązującego prawa. Ponieważ nie ma możliwości ani nadania temu przepisowi treści zgodnej z dyrektywą, ani wyłączenia jego stosowania, to podstawą normatywną rozstrzygnięcia Urzędu Patentowego i sądów administracyjnych jest ten przepis pomimo jego sprzeczności z normą pochodnego prawa unijnego. Osobie fizycznej lub osobie prawnej przysługuje ewentualne roszczenie odszkodowawcze wobec państwa ze względu na naruszenie obowiązku implementacji normy prawa unijnego. Oczywiście ta osoba, wytaczając odpowiednie powództwo, powinna udowodnić wszystkie przesłanki tej odpowiedzialności. ${ }^{62}$ Generalne stanowisko o przesłankach tej odpowiedzialności znalazło także ostatnio wyraz w orzecznictwie polskiego Sądu Najwyższego. ${ }^{63}$

Każdy z wyżej przedstawionych wariantów oceny normy art. 165 ust. 1 pkt 2 $\mathrm{w}$ świetle prawa unijnego może budzić rozmaite wątpliwości i zastrzeżenia. W przekonaniu autora niniejszego tekstu, najbardziej znaczące są argumenty przemawiające za trzecim stanowiskiem, które przyjmuje obowiązywanie art. 165 ust. 1 pkt 2 ustawy pomimo jego sprzeczności z art. 3 ust. 3 zd. 2 dyrektywy. Stosuje się zatem art. 165 ust. 1 pkt 2 ustawy, a osobie, której wyrządzono szkodę w następstwie nieprawidłowej implementacji przysługuje wobec państwa roszczenie odszkodowawcze.

\section{Wnioski końcowe}

Na podstawie orzecznictwa sądów unijnych, w szczególności Trybunału Sprawiedliwości, można ustalić metodykę działań organu orzekającego (Urzędu Patentowego, sądów administracyjnych) przy ustalaniu nabycia zdolności odróżniającej przez znak towarowy w następstwie używania. Kolejność tych działań przedstawia się następująco:

1. Należy określić, czy znak towarowy ma pierwotną zdolność odróżniającą.

Dopiero uzyskanie odpowiedzi przeczącej uzasadnia przejście do oceny nabycia wtórnej zdolności odróżniającej, jeżeli zgłaszający twierdzi, iż to oznaczenie legitymuje się taką zdolnością i przedstawić odpowiednie dowody na poparcie swojego stanowiska.

2. Określa, czy zgłoszony znak towarowy jest tożsamy z używanym znakiem dla tych samych towarów. Brak tej zgodności czyni bezzasadnym dalsze badania.

\footnotetext{
62 Zob. zamiast wielu wyrok TS z dnia 23 kwietnia 2009 r. w połączonych sprawach C-378/07 do 380/07, Kiriaki Angelidaki i inni p. Organismos Nomarchiakis Autodioikisis Rethymnis (C-378/07), Charikleia Giannoudi p. Dimos Geropotamou (C-379/07) i Georgios Karabousanos i Sofoklis Michopoulos p. Dimos Geropotamou (C-380/07), pkt 202 wraz z powołanym tam orzecznictwem, www.curia.europa.eu (data dostępu: 11.09.2015 r.). Zob. wyrok SN z dnia 19 czerwca 2013 r., I CSK 392/12, LEX nr 1365589, OSNC-ZD 2014/3/58.
} 
3. Ustalić, czy zgłoszone oznaczenie jest używane w charakterze znaku towarowego. To używanie powinno wyrażać się w rozpoznawaniu oznaczenia przez odbiorców towarów pod tym znakiem jako pochodzących z jednego i tego samego przedsiębiorstwa (związku przedsiębiorstw pozostających pod jednolitą kontrolą).

4. Używanie to powinno być wykazane w odniesieniu do całego terytorium Polski. Nie jest oczywiście wymagane równie intensywne używanie oznaczenia na całym terytorium.

5. Należy określić krąg osób, do których są adresowane towary (usługi) pod tym znakiem. Następnie ustalić model osoby przeciętnego nabywcy tych towarów jako osoby dobrze poinformowanej, wystarczająco uważnej i racjonalnej.

6. W celu ustalenia, czy znak towarowy uzyskał charakter odróżniający w następstwie używania, należy przeprowadzić całościową ocenę dowodów, które mogą wykazać, że znak stał się zdolny do identyfikowania towarów na podstawie ich pochodzenia i tym samym odróżniania tych towarów od towarów innych przedsiębiorstw.

7. Charakter odróżniający oznaczenia podlega ocenie, z jednej strony w odniesieniu do towarów, a $\mathrm{z}$ drugiej strony przypuszczalnego sposobu postrzegania przez właściwie (dobrze) poinformowanego, wystarczająco uważnego i racjonalnego nabywcę towarów tej kategorii.

8. Ocena charakteru odróżniającego znaku towarowego powinna być dokonana na datę zgłoszenia znaku towarowego (data pierwszeństwa). Pod uwagę bierze się jedynie dowody, które pozwalają ocenić charakter odróżniający znaku na tę datę.

Powyższe zasady dotyczące nabycia zdolności odróżniającej przez używanie oznaczenia przed datą zgłoszenia (data pierwszeństwa) w coraz szerszym stopniu znajdują wyraz także w praktyce Urzędu Patentowego i sądów administracyjnych. Świadczy o tym w szczególności obszerne orzecznictwo Urzędu Patentowego i Wojewódzkiego Sądu Administracyjnego dotyczące oznaczeń liczbowych dla wydawnictw szaradziarskich. ${ }^{64}$ Można oczekiwać, iż te zasady, z czasem, staną się utrwaloną linią orzekania w zakresie wtórnej zdolności odróżniającej.

Odrębną kwestią jest ocena regulacji w prawie polskim wtórnej zdolności odróżniającej oznaczeń nabytej poprzez używanie przez oznaczenie, które nie były

64 Zob. wyrok NSA z dnia 20 grudnia 2012 r., sygn. II GSK 1278/11 w sprawie o unieważnienie prawa ochronnego na znak słowno-graficzny „300”; wyrok NSA z dnia 24 lipca 2013 r., sygn. II GSK 38/12, w sprawie o unieważnienie prawa ochronnego na znak słowno-graficzny „300”; wyrok NSA z dnia 2 października 2014 r. w sprawie II GSK 714/13 w sprawie o unieważnienie prawa ochronnego na znak słowno-graficzny „500”; wyrok NSA z dnia 14 listopada 2014 r. sygn. II GSK 1605/13 w sprawie o unieważnienie prawa ochronnego na znak słowno-graficzny „200”, www.nsa.gov.pl (data dostępu: 11.09.2015 r.). 
wyposażone w tę cechę w dacie zgłoszenia (data pierwszeństwa). Analiza art. 165 ust. 1 pkt 2 prowadzi do następujących wniosków:

1. Przepis ten budzi zasadnicze wątpliwości z punktu widzenia swojej zgodności z prawem unijnym. Stąd należałoby sugerować skierowanie pytań prejudycjalnych do Trybunału w kwestii wykładni art. 3 ust. 3 zd. 2 dyrektywy, a mianowicie, czy ten przepis dyrektywy dozwala na przyjęcie normy o treści w art. 165 ust. 1 pkt 2.

2. Do czasu rozstrzygnięcia Trybunału przepis art. 165 ust. 1 pkt 2 obowiązuje i powinien być stosowany. Jednakże osobie, której wyrządzono szkodę w następstwie nieprawidłowej implementacji - przy założeniu, iż przepis ten jest sprzeczny z prawem unijnym - służy roszczenie odszkodowawcze.

3. Przepis art. 165 ust. 1 pkt 2, jako norma wyjątkowa, podlega ścisłej wykładni. W szczególności stosuje się jedynie do znaków towarowych zgłoszonych do rejestracji w Urzędzie Patentowym pod rządami obowiązującej ustawy.

4. Przy ocenie nabycia wtórnej zdolności odróżniającej zarejestrowanych znaków towarowych pozbawionych zdolności odróżniającej w dacie zgłoszenia (pierwszeństwa), w odniesieniu do których uprawniony powołuje się na art. 165 ust. 1 pkt 2, znajdują odpowiednie zastosowanie wyżej wymienione zasady dotyczące nabycia wtórnej zdolności odróżniającej na datę zgłoszenia (art. 130). 


\section{THE ACQUIRED DISTINCTIVE CHARACTER OF A TRADE MARK AS A CONSEQUENCE OF ITS USE (GROUNDS, DATES AND PROOF OF USE)}

The subject of this commentary - the acquired distinctive character of a trade mark as a consequence of its use - is a very practical issue. Especially with regard to the grounds, dates and proof of use necessary to establish the acquired distinctive character of a trade mark which was devoid of inherent distinctive character. The Author provides an interpretation of the appropriate regulations laid down in the Industrial Property Act of 2000. He also takes into consideration the newest judgments of the EU Court of Justice based on a reference for a preliminary ruling. Discussing the criteria for establishing the acquired distinctiveness and the methodology for its correct evaluation. Another issue addressed is the evaluation of the provision of the Polish law where the distinctive character of the trade mark was acquired as a consequence of the use of that trade mark after the date of its application for registration. Article 165 (1) (3) of the Industrial Property Act, which addresses the issue of acquired distinctiveness, raises considerable doubts as to its accordance with EU law. Therefore, the Author suggests that a reference for a preliminary ruling should be raised. However until such a judgment is made the current meaning of the said Article needs to be applied. It should, nevertheless, be subject to very strict interpretation, especially with regard to trade marks which were applied for registration under the currently applicable law.

Słowa kluczowe: znak towarowy, wtórna zdolność odróżniającą, orzecznictwo Trybunału Sprawiedliwości UE, ustawa Prawo własności przemysłowej, zgodność z prawem UE

Keywords: trade mark, acquired distinctiveness, CJEU case-law, IP Law Act, conformity with EU law 